\title{
Ailleurs. Au même instant
}

\author{
Germaine Beaulieu
}

The oeuvre of Germaine Beaulieu is throughout marked by a feminist engagement and an equally intense preoccupation with themes of existence, the real, love, sensuality, and absence. This is a writing of dérive, of desire, of the call to the other, a writing in which life borders death in surges of metamorphosis and mutation. Committed to constant exploration, Beaulieu refuses to settle for truths that would stop the flow of this creative impulse.

À la dictature du cercle
Mon corps est soumis
De peine lourde mon âme
Je suis de désir et de mort
La noirceur l'essentiel et l'ailleurs
Auront une belle odeur de pierre cassée.

Près du cœur souffle

Souffle fort

Arme moi perds moi

Dans les couloirs de satin

Je guette

Oh! Surprise

Sur mon épaule

Encore ton visage

$D^{\prime}$ amour. 